\title{
Effect of increasing doses of marigold (Tagetes erecta) flower extract on eggs carotenoids content, colour and oxidative stability
}

\author{
M. Skřivan ${ }^{1,3}$, M. Marounek ${ }^{1}$, M. Englmaierová1 and E. Skřivanová ${ }^{1,2}$ \\ ${ }^{1}$ Institute of Animal Science, Department of Nutrition Physiology and Animal Product Quality \\ Prátelství 815, CZ-104 00, Prague, Czech Republic \\ ${ }^{2}$ Czech University of Life Sciences Prague \\ Faculty of Agrobiology, Food and Natural Resources, Department of Microbiology, Nutrition and Dietetics \\ Kamýcká 129, CZ-165 21, Prague, Czech Republic
}

KEY WORDS: marigold flower extract, egg production, yolk colour, carotenoids, oxidative stability

Received: 27 November 2014

Revised: 22 January 2016

Accepted: $\quad 10$ March 2016

${ }^{3}$ Corresponding author:

e-mail: skrivan.milos@vuzv.cz

\begin{abstract}
Two hundred and forty hens were assigned to six dietary treatments and fed a maize-wheat-soyabean diet supplemented per $\mathrm{kg}$ with 0, 150, 350, 550, 750 and $950 \mathrm{mg}$ of marigold flower extract (MFE) containing lutein and zeaxanthin in the amount of 21.26 and $9.65 \mathrm{mg} \cdot \mathrm{kg}^{-1}$, respectively. There was observed no MFE addition effect on hens body weight and feed conversion ratio. The higher hen-day egg production was stated for group fed diet supplemented with 550 and $950 \mathrm{mg}$ of MFE per kg of diet, whereas egg weight was increased in groups fed 550 and $750 \mathrm{mg}$ MFE per $\mathrm{kg}$ of diet. The treatment effects on the albumen parameters, and yolk and shell percentages were not statistically significant. Dietary MFE addition increased the yolk colour score (DSM Yolk Colour Fan), and redness and yellowness of the yolks but decreased their lightness. Supplementation of MFE increased the lutein and zeaxanthin concentration in the egg yolks in a dose-dependent manner, from 12.34 and $5.92 \mathrm{mg} \cdot \mathrm{kg}^{-1}$ dry matter (control) to 36.33 and $25.59 \mathrm{mg} \cdot \mathrm{kg}^{-1}$ dry matter (group fed diet with $950 \mathrm{mg} \mathrm{MFE}$ per $\mathrm{kg}$ ), respectively. No treatment effect on the concentrations of retinol and a-tocopherol in the yolk was observed. Dietary MFE significantly increased the oxidative stability of eggs lipids stored at $18^{\circ} \mathrm{C}$ for 28 days. It can be concluded that 1 . hen diet supplementation with MFE provides the yolk pigmentation required by consumers, and 2 . MFE (in the amount of $550 \mathrm{mg} \cdot \mathrm{kg}$ diet) is a suitable alternative to commercial synthetic xanthophylls.
\end{abstract}

\section{Introduction}

Xanthophylls belong to a sub-class of carotenoids and contain at least one oxygen atom in their molecular structure. Currently, there is an increasing interest in xanthophylls use in human food and animal feed applications. In poultry farming, synthetic xanthophylls are used as feed supplements to obtain optimum colouring of the broiler skin and, especially, of the egg yolk. The preferred synthetic red xanthophyll used in poultry farming is canthaxanthin, and the preferred yellow one is $\beta$-apo- $8^{\prime}$ carotenoic acid ethyl ester. The intensity as well as the colour of the yolk can be controlled by the type 
and concentration of dietary xanthophylls. Both xanthophylls are available commercially on the market as Carophyll ${ }^{\circledR}$ Red and Carophyll ${ }^{\circledR}$ Yellow (DSM Nutritional Products, Basel, Switzerland) and Lucantin ${ }^{\circledR}$ Red and Lucantin ${ }^{\circledR}$ Yellow (BASF, Ludwigshafen, Germany). The carotenoids present in plants are promising alternative to synthetic xanthophylls.

Karadas et al. (2006) investigated the effects of lucerne concentrate, tomato powder and marigold extract as feed additives for quails on yolk pigmentation and the deposition of carotenoids in eggs. The concentrations of lutein, zeaxanthin, lycopene and $\beta$-carotene were increased in the eggs of quails fed diets supplemented with natural carotenoids compared with the control group. Lokaewmanee et al. (2009) reported higher pigmentation scores for yolk colour in the eggs of hens fed diet supplemented with mulberry leaves. Hammershøj et al. (2010) examined the effects of orange, yellow and purple carrots on the deposition of carotenoids in hens. Supplementing the feed of layers with coloured carrots significantly increased the total carotenoid content in the egg yolk; in particular, purple carrots increased the lutein content in the yolk. The yolk colour and carotenoid content were also positively correlated. Several researchers supplemented the laying hens diets with freshwater or marine algae. Mader et al. (1984) reported that the fortification of a commercial feed mixture with disintegrated and spray-dried algae Scenedesmus obliquus at a dose from 10 to $60 \mathrm{~g} \cdot \mathrm{kg}^{-1}$ resulted in several-fold increase in carotenoid levels both in the feed and in the yolk. At the same level of carotenoids in the feed, the yolk pigmentation effect of algae was higher than that of lucerne. Marine algae Spirulina platensis was used in the experiment of Zahroojian et al. (2011) who concluded that a diet containing $2.5 \% \mathrm{~S}$. platensis could be as effective as a diet with the synthetic pigments Lucantin ${ }^{\circledR}$ Red and Lucantin ${ }^{\circledR}$ Yellow at dose of 35 and $30 \mathrm{mg} \cdot \mathrm{kg}^{-1}$, respectively. Kotrbáček et al. (2013) who studied the effect of supplementation of the commercial hens diets with heterotrophic Chlorella, observed that total carotenoids deposition increased by 46 and $119 \%$ when diets were supplemented with 10 and $20 \mathrm{~g} \cdot \mathrm{kg}^{-1}$, respectively. Lutein and zeaxanthin represented more than $90 \%$ of the total carotenoids in the yolk. The deposition of carotenoids increased the pigmentation score of the yolk. Englmaierová et al. (2013) compared the effects of lutein, spray-dried Chlorella (cultivated autotrophically), and the synthetic xanthophylls Carophyll ${ }^{\circledR}$ Red and Carophyll ${ }^{\circledR}$ Yellow on the laying hen performance, yolk colour and oxidative stability of yolk lipids. Supplementation of the feed with lutein $\left(250 \mathrm{mg} \cdot \mathrm{kg}^{-1}\right)$ and Chlorella $\left(12.5 \mathrm{~g} \cdot \mathrm{kg}^{-1}\right)$ significantly increased the concentration of lutein and zeaxanthin in yolks, increased the yolk colour, and improved the oxidative stability of the lipids of fresh eggs and eggs stored for 28 days. The contents of carotenoids and yolk pigmentation were increased also in the eggs of hens fed diet supplemented with marine algae Nannochloropsis oculata (Fredriksson et al., 2006) and Sargassum dentifebium (Al-Harthi and El-Deek, 2012).

The currently being tested natural carotenoids are too expensive; therefore, they are unprofitable in practical applications. In contrary, flowers of marigold (Tagetes erecta) are profitable in practice and are among the best known natural sources of pigmentation for feed additives. Thus, the purpose of the present study was to evaluate the effect of marigold extract on the performance of laying hens, the quality parameters of eggs, the yolk colour, the yolk content of lutein, zeaxanthin, vitamins A and E, and the oxidative stability of yolk lipids. The doseresponse efficacy of the marigold flower extract supplementation was assessed.

\section{Material and methods}

\section{Hens, diets and husbandry}

The experiment was approved by the Ethical Committee of the Institute of Animal Science (the Czech Republic).

Two hundred and forty 30-week old Lohmann Brown hens were used in the experiment. The experiment lasted 12 weeks (including 2 weeks of a preliminary period). The hens were housed in threefloor enriched cages, with 10 hens per cage. The cage provided $0.76 \mathrm{~m}^{2}$ of floor area, which did not include the nest, $120 \mathrm{~cm}$ for the feeder and 3 nipple water dispensers. The cages were equipped with a nest box, perch, dust bath and equipment for the abrasion of claws (EU Council Directive 1999/74/EC, 1999). The cages were placed in the same air-conditioned facility at $20-22^{\circ} \mathrm{C}$ with $16 \mathrm{~h}$ of light and $8 \mathrm{~h}$ of darkness.

The hens were randomly assigned to one of the six dietary treatments, each with 4 replicate cages. The control group was fed a ground basal maizewheat-soyabean diet (Table 1). The experimental groups received diets supplemented with 150, 350, 550, 750 and $950 \mathrm{mg}$ of Avizant ${ }^{\circledR}$ Yellow $20 \mathrm{HS}$ (Lohmann Animal Health, Cuxhaven, Germany) per $\mathrm{kg}$ of diet. Avizant ${ }^{\mathbb{B}}$ Yellow $20 \mathrm{HS}$ is the extract of marigold flowers containing $21.26 \mathrm{~g}$ of lutein and $9.65 \mathrm{~g}$ of zeaxanthin per kg. Marigold flowers were shredded and dehydrated with a drum dryer and the 
Table 1. Ingredients and analysed chemical composition of basal diet ${ }^{1}$

\begin{tabular}{|c|c|}
\hline Indices & Basal diet \\
\hline \multicolumn{2}{|l|}{ Ingredients, $\mathrm{g} \cdot \mathrm{kg}^{-1}$} \\
\hline maize & 350 \\
\hline wheat & 280 \\
\hline soyabean meal & 210.5 \\
\hline rapeseed oil & 30 \\
\hline lucerne meal & 20 \\
\hline limestone (1 - $2 \mathrm{~mm})$ & 91 \\
\hline dicalcium phosphate & 9 \\
\hline $\mathrm{NaCl}$ & 2 \\
\hline DL-methionine & 1.5 \\
\hline L-lysine & 1 \\
\hline vitamin-mineral premix² & 5 \\
\hline \multicolumn{2}{|l|}{ Analysed chemical composition, $\mathrm{g} \cdot \mathrm{kg}^{-1}$} \\
\hline dry matter & 901.2 \\
\hline crude protein & 171.7 \\
\hline calcium & 37.3 \\
\hline phosphorus & 5.6 \\
\hline Nitrogen-corrected apparent $\mathrm{ME}^{3}, \mathrm{MJ} \cdot \mathrm{kg}^{-1}$ & 11.4 \\
\hline \multicolumn{2}{|c|}{$\begin{array}{l}{ }^{1} \text { other experimental diets were supplemented with } 150,350,550,750 \\
\text { or } 950 \mathrm{mg} \cdot \mathrm{kg}^{-1} \text { of Avizant }{ }^{\circledR} \text { Yellow } 20 \mathrm{HS} \text {, which was added at expense } \\
\text { of limestone; }{ }^{2} \text { premix provided per } \mathrm{kg} \text { of diet: IU: vit. D } 3000 \text {; mg: } \\
\text { retinyl acetate } 3 \text {, vit. E } 30 \text {, niacin } 25 \text {, Ca pantothenate } 8 \text {, thiamine } 2 \text {, thin } \\
\text { riboflavin } 5 \text {, pyridoxine } 4 \text {, folic acid } 0.5 \text {, biotin } 0.075 \text {, cobalamin } 0.01 \text {, } \\
\text { choline } \mathrm{Cl} 250 \text {, menadione } 2 \text {, betaine } 100 \text {, butylated hydroxytolu- } \\
\text { ene } 7.5 \text {, ethoxyquin } 5.6 \text {, butylhydroxyanisole } 1 \text {, DL-methionine } 0.7 \text {, } \\
\text { Mn } 70 \text {, Zn } 50 \text {, Fe } 40 \text {, Cu } 6, I 1 \text {, Co } 0.3 \text {, Se } 0.2 ;{ }^{3} \mathrm{ME} \text { - metabolizable } \\
\text { energy }\end{array}$} \\
\hline
\end{tabular}

carotenoids were extracted using an organic solvent (hexane). Calcium carbonate was the major component of Avizant ${ }^{\mathbb{R}}$ Yellow 20 HS. Therefore, Avizant ${ }^{\mathbb{R}}$ Yellow $20 \mathrm{HS}$ was dosed at the expense of limestone. Extract of marigold flowers was added into the vitamin-mineral premix. Feed and fresh water were supplied ad libitum.

\section{Sampling and measurements}

Eggs were collected daily, whereas the performance parameters were calculated weekly (feed intake and eggs weight per cage and group). The body weight was recorded in the 32 and 41 week of hen life. In the week 3, 6 and 9 of the study, the eggs were collected for analysis of the physical characteristics (Englmaierová et al., 2015). Once within each collection period, a whole-day egg production was analysed. All eggs laid in $24 \mathrm{~h}$ were collected at 7:00 and immediately analysed. In total 574 eggs were analysed. The technological parameters included: the eggs weight, the shell weight, thickness and breaking strength, the albumen index, the Haugh units and the yolk colour. The shell weight with membranes was determined after drying at $105^{\circ} \mathrm{C}$. The eggshell thickness (the average at both ends and at the middle, including shell membranes) was measured with a micrometer. The shell breaking strength and deformation were measured on the vertical axis using Instron 3360 equipment (Instron, Canton, MA, USA). The albumen height was measured using a tripod micrometer and Haugh units were calculated, as indicated by Haugh (1937). The albumen and yolk index were calculated as a ratio between the height and diameter of the albumen and the yolk, respectively. The yolk colour was determined using the DSM Yolk Colour Fan (DSM Nutritional Products, Basel, Switzerland) and Minolta CR-300 colorimeter (Konica Minolta, Osaka, Japan). The $L^{*}, a^{*}, b^{*}$ parameters correspond to the lightness, redness and yellowness, respectively.

\section{Laboratory analyses}

Two hundred and sixteen eggs were evaluated for the vitamin and carotenoid content in their yolks during the week 9 of the experiment [ 6 (treatments) $\times 12$ (number of samples per treatment) $\times 3$ (one sample consisted of a mixture of 3 egg yolks) $=216$ eggs]. The content of lutein and zeaxanthin in the yolks was measured by high-performance liquid chromatography (HPLC) according to a modified method of Froescheis et al. (2000) with a use of HPLC instrument (VP series; Shimadzu, Kyoto, Japan) equipped with a diode-array detector. The $\alpha$-tocopherol, retinol and $\beta$-carotene content in the yolks were determined in accordance with the European standards EN 12822 (2000), EN 12823-1 (2000) and EN 12823-2 (2000), respectively. The lipid peroxidation level in the yolks of fresh eggs $(n=12)$ and eggs stored for 28 days at $18^{\circ} \mathrm{C}(\mathrm{n}=12)$ was assayed using the thiobarbituric acid method (Piette and Raymond, 1999).

The feed and yolk dry matter was determined by drying in oven (Memmert ULM 500; Memmert, Schwabach, Germany) at $105^{\circ} \mathrm{C}$ to a constant weight, and the feed crude protein content was measured using Kjeltec Auto 1030 instrument (Tecator, Höganäs, Sweden). Analyses of the P and Ca content in the diets were conducted. Dry homogenized diets were ashed in a muffle furnace (LAC Ht40 AL; LAC, Ltd., Rajhrad, Czech Republic) at $550{ }^{\circ} \mathrm{C}$, and the ash was dissolved in $3 \mathrm{M}$ hydrochloric acid and quantitatively transferred into a volumetric flask. The total $\mathrm{P}$ in the solution was determined using a vanadate-molybdate reagent (AOAC International, 2005; method No. 965.17) and the Ca concentration in the hydrochloric acid extract was measured by atomic absorption spectrometry using a Solaar M6 instrument (TJA Solutions, Cambridge, UK). The vitamins and carotenoids contents in the feed and Avizant were determined using the methods described above. 


\section{Statistical analysis}

The data was analysed using analysis of variance (ANOVA) with the General Linear Models (GLM) procedure using SAS software (SAS v 9.2, 2003). A one-way analysis of variance was used. The main effect was the dose of MFE in diet. All differences were considered significant at $P<0.05$. The results in the tables are presented as mean \pm standard error of mean (SEM).

\section{Results and discussion}

The marigold flower extract (MFE; Avizant ${ }^{\circledR}$ Yellow 20 HS) used in this study contained $21.26 \mathrm{~g}$ of lutein and $9.65 \mathrm{~g}$ of zeaxanthin per $\mathrm{kg}$ (the results of the analyses carried out in the Institute of Animal Science, the Czech Republic). Whereas, the manufacturer declared total xanthophylls content as $20 \mathrm{~g}$ per kg mainly consisting of lutein (17 g per $\mathrm{kg}$ ). The manufacturer showed lower values of these active compounds, especially at the end of the period of validity, as the carotenoids are very unstable. The hen diet supplementation with MFE increased the dietary content of lutein from 1.01 to $4.86 \mathrm{mg} \cdot \mathrm{kg}^{-1}$ and that of zeaxanthin from 0.69 to $6.55 \mathrm{mg} \cdot \mathrm{kg}^{-1}$ in a dose-dependent manner but did not increase the content of $\beta$-carotene, retinol or $\alpha$-tocopherol (Table 2).

The MFE addition into diet did not influence hen body weight at the end of the experiment; however feed intake decreased in group fed diet supplemented with $150 \mathrm{mg}$ of the MFE per $\mathrm{kg}$ of diet (Table 3).

Table 2. Effect of marigold flower extract addition into hen diet on carotenoids, vitamin A and vitamin E content in diets, $\mathrm{mg} \cdot \mathrm{kg}^{-1} \mathrm{DM}^{1}$

\begin{tabular}{lcccccc}
\hline \multirow{2}{*}{ Indices } & \multicolumn{6}{c}{ Marigold flower extract dose, $\mathrm{mg} \cdot \mathrm{kg}^{-1}$ diet } \\
\cline { 2 - 7 } & 0 & 150 & 350 & 550 & 750 & 950 \\
\hline Lutein & 1.01 & 2.36 & 3.85 & 4.86 & 9.01 & 9.52 \\
Zeaxanthin & 0.69 & 1.55 & 2.46 & 3.42 & 6.55 & 7.16 \\
B-Carotene & 0.31 & 0.55 & 0.28 & 0.49 & 0.38 & 0.42 \\
Retinol & 1.79 & 3.84 & 1.81 & 1.67 & 2.27 & 2.64 \\
$\alpha$-Tocopherol & 24.6 & 29.5 & 25.4 & 23.9 & 25.3 & 28.7 \\
\hline
\end{tabular}

${ }^{1} \mathrm{DM}$ - dry matter
Also Chowdhury et al. (2008) showed that the use of $4 \%$ marigold in the diet of laying pullets had no effect on body weight and feed consumption. Similar results mentioned Altuntaş and Aydin (2014) in 80 -week-old hens fed diet supplemented with 0,10 or $20 \mathrm{~g}$ of marigold flour per $\mathrm{kg}$ of diet.

Both 550 and $950 \mathrm{mg}$ of MFE per $\mathrm{kg}$ of diet additions increased hen-day egg production in comparison to control group. Also the egg weight was influenced by MFE supplementation and was increased in groups fed diet containing 150, 550 and $750 \mathrm{mg}$ of MFE per $\mathrm{kg}$ of diet in comparison to control group. The feed conversion calculated as $\mathrm{g}$ of feed per egg did not differ between all groups. MFE addition did not influence albumen parameters (albumen percentage, height and index), but there were observed changes in some parameters describing yolk in experimental groups. The supplementation of MFE in the amount of 550 and $950 \mathrm{mg} \cdot \mathrm{kg}^{-1}$ significantly decreased yolk height and yolk index. The shell thickness was increased in group fed diet supplemented with $550 \mathrm{mg}$ of MFE per $\mathrm{kg}$ of diet. Also in this group the shell deformation was decreased. The shell breaking strength was decreased after MFE addition in the amount of 150 and $950 \mathrm{mg}$ per $\mathrm{kg}$ of diet. The shell percentage did not differ between all groups. In contrast to these results, Chowdhury et al. (2008), Lokaewmanee et al. (2011) and Altuntaş and Aydin (2014) did not record the effect of marigold supplementation on the egg production and egg quality parameters.

The hen diet supplementation with MFE significantly increased the concentration of lutein and zeaxanthin in eggs in a dose-dependent manner (from 12.34 to $36.33 \mathrm{mg} \cdot \mathrm{kg}^{-1}$ of dry matter, and from 5.92 to $25.59 \mathrm{mg} \cdot \mathrm{kg}^{-1}$ of dry matter, respectively) (Table 5). In fresh eggs only the highest MFE addition decreased lipid peroxidation level in comparison to control group; however the lipid oxidative stability in eggs stored for 28 days at $18{ }^{\circ} \mathrm{C}$ was significantly improved by all marigold flower extract additions. There was no treatment effect on

Table 3. Effect of marigold flower extract addition into hen diet on hen performance between 32 and 41 week of laying period

\begin{tabular}{|c|c|c|c|c|c|c|c|c|}
\hline \multirow{2}{*}{ Indices } & \multicolumn{6}{|c|}{ Marigold flower extract dose, $\mathrm{mg} \cdot \mathrm{kg}^{-1}$ diet } & \multirow{2}{*}{ SEM } & \multirow{2}{*}{$P$} \\
\hline & 0 & 150 & 350 & 550 & 750 & 950 & & \\
\hline Body weight in 32 week, $g$ & 1863 & 1758 & 1815 & 1789 & 1849 & 1762 & 9.0 & NS \\
\hline Body weight in 41 week, g & 1919 & 1868 & 1778 & 1897 & 1824 & 1979 & 22.3 & NS \\
\hline Hen-day egg production, $\%$ & $85.3^{\text {bc }}$ & $82.0^{c}$ & $85.2^{\mathrm{bc}}$ & $91.1^{\mathrm{a}}$ & $85.8^{\mathrm{b}}$ & $90.1^{\mathrm{a}}$ & 0.62 & $<0.001$ \\
\hline Egg weight, g & $63.5^{\mathrm{c}}$ & $64.3^{\mathrm{ab}}$ & $63.8^{\mathrm{bc}}$ & $65.0^{\mathrm{a}}$ & $65.1^{\mathrm{a}}$ & $63.8^{\mathrm{bc}}$ & 0.11 & $<0.001$ \\
\hline Total mass of all eggs laid during the experiment, $\mathrm{kg} \cdot \mathrm{hen}^{-1}$ & 3.79 & 3.69 & 3.81 & 4.15 & 3.91 & 4.04 & 0.059 & NS \\
\hline Feed intake, $g \cdot$ day $^{-1}$ per hen & $115.8^{\mathrm{ab}}$ & $110.8^{c}$ & $113.4^{\mathrm{bc}}$ & $118.6^{\mathrm{a}}$ & $117.3^{\mathrm{a}}$ & $116.8^{\mathrm{ab}}$ & 0.55 & $<0.001$ \\
\hline Feed conversion, $\mathrm{g}$ feed $\cdot \mathrm{g}^{-1} \mathrm{egg}$ & 2.18 & 2.15 & 2.14 & 2.05 & 2.14 & 2.08 & 0.02 & NS \\
\hline
\end{tabular}

abc means with different superscipts within a row are significantly different, NS - not significant 
Table 4. Effect of marigold flower extract addition into hen diet on eggs quality

\begin{tabular}{|c|c|c|c|c|c|c|c|c|}
\hline \multirow[b]{2}{*}{ Indices } & \multicolumn{6}{|c|}{ Marigold flower extract dose, $\mathrm{mg} \cdot \mathrm{kg}^{-1}$ diet } & \multirow[b]{2}{*}{ SEM } & \multirow[b]{2}{*}{$P$} \\
\hline & $\begin{array}{l}0 \\
(n=89)\end{array}$ & $\begin{array}{l}150 \\
(n=99)\end{array}$ & $\begin{array}{l}350 \\
(n=100)\end{array}$ & $\begin{array}{l}550 \\
(n=90)\end{array}$ & $\begin{array}{l}750 \\
(n=100)\end{array}$ & $\begin{array}{l}950 \\
(n=96)\end{array}$ & & \\
\hline Albumen percentage, $\%$ & 65.9 & 66.1 & 65.7 & 66.1 & 65.8 & 65.6 & 0.08 & NS \\
\hline Albumen height, mm & 7.53 & 7.76 & 7.65 & 8.01 & 7.93 & 7.60 & 0.14 & NS \\
\hline Albumen index, \% & 9.48 & 9.65 & 9.51 & 9.53 & 9.78 & 9.34 & 0.17 & NS \\
\hline Haugh units & 85.1 & 86.7 & 85.9 & 83.6 & 87.2 & 85.5 & 0.37 & NS \\
\hline Yolk/albumen ratio, \% & 36.4 & 36.5 & 37.2 & 36.0 & 36.6 & 37.1 & 0.16 & NS \\
\hline Yolk percentage, $\%$ & 24.0 & 24.0 & 24.4 & 23.7 & 24.0 & 24.3 & 0.08 & NS \\
\hline Yolk height, mm & $18.6^{a}$ & $18.5^{\mathrm{ab}}$ & $18.6^{a}$ & $18.2^{\mathrm{c}}$ & $18.7^{\mathrm{a}}$ & $18.3^{b c}$ & 0.04 & $<0.001$ \\
\hline Yolk index, \% & $45.6^{a}$ & $45.1^{\mathrm{ab}}$ & $44.8^{\mathrm{bc}}$ & $44.3^{c}$ & $45.2^{\mathrm{ab}}$ & $44.4^{c}$ & 0.11 & 0.002 \\
\hline \multicolumn{9}{|l|}{ Yolk colour ${ }^{1}$} \\
\hline DSM Yolk Colour Fan & $5.67^{\dagger}$ & $7.31^{\mathrm{e}}$ & $8.52^{d}$ & $8.93^{c}$ & $9.51^{\mathrm{b}}$ & $10.55^{a}$ & 0.071 & $<0.001$ \\
\hline$L^{*}$ & $64.29^{a}$ & $62.38^{b}$ & $62.09^{b}$ & $61.78^{\mathrm{bc}}$ & $60.55^{\text {cd }}$ & $59.27^{d}$ & 0.202 & $<0.001$ \\
\hline$a^{*}$ & $4.94^{f}$ & $6.17^{\mathrm{e}}$ & $7.77^{\mathrm{d}}$ & $9.04^{c}$ & $10.54^{b}$ & $11.51^{\mathrm{a}}$ & 0.108 & $<0.001$ \\
\hline$b^{*}$ & $46.98^{d}$ & $50.79^{c}$ & $53.78^{b}$ & $55.59^{a}$ & $56.30^{a}$ & $56.49^{a}$ & 0.204 & $<0.001$ \\
\hline Shell percentage, \% & 10.1 & 9.9 & 10.0 & 10.1 & 10.1 & 10.1 & 0.03 & NS \\
\hline Shell thickness, $\mu \mathrm{m}$ & $351^{b}$ & $343^{b}$ & $349^{b}$ & $369^{a}$ & $355^{\mathrm{ab}}$ & $350^{b}$ & 2.32 & 0.040 \\
\hline Shell deformation, mm & $0.50^{\mathrm{ab}}$ & $0.49^{b c}$ & $0.51^{\mathrm{a}}$ & $0.48^{c}$ & $0.49^{b c}$ & $0.48^{\mathrm{bc}}$ & 0.01 & 0.002 \\
\hline Shell breaking strength, $\mathrm{g} \cdot \mathrm{cm}^{-2}$ & $4431^{a}$ & $4197^{c}$ & $4448^{a}$ & $4256^{\mathrm{abc}}$ & $4415^{\mathrm{ab}}$ & $4205^{b c}$ & 31.9 & 0.040 \\
\hline
\end{tabular}

'DSM Yolk Colour Fan - egg yolk colour measured with DSM Yolk Color Fan, $L^{*}$ - lightness, $a^{*}$ - redness, $b^{*}$ - yellowness; ${ }^{\text {a-f }}$ means with different superscipts within a row are significantly different; NS - not significant

Table 5. Effect of marigold flower extract addition into hen diet on content of carotenoids, vitamin $A$ and vitamin $E$ in egg yolks and lipid peroxidation level ${ }^{1}$ in fresh $\left(\mathrm{MDA}_{0}\right)$ and stored for 28 days $\left(\mathrm{MDA}_{28}\right)$ eggs

\begin{tabular}{|c|c|c|c|c|c|c|c|c|}
\hline \multirow[b]{2}{*}{ Indices } & \multicolumn{8}{|c|}{ Marigold flower extract dose, $\mathrm{mg} \cdot \mathrm{kg}^{-1}$ diet } \\
\hline & 0 & 150 & 350 & 550 & 750 & 950 & SEM & $P$ \\
\hline \multicolumn{9}{|c|}{$n=12$} \\
\hline Lutein, $\mathrm{mg} \cdot \mathrm{kg}^{-1} \mathrm{DM}^{2}$ & $12.34^{\mathrm{e}}$ & $18.56^{\mathrm{d}}$ & $29.11^{c}$ & $30.27^{\mathrm{bc}}$ & $30.80^{b}$ & $36.33^{a}$ & 1.09 & $<0.001$ \\
\hline Zeaxanthin, $\mathrm{mg} \cdot \mathrm{kg}^{-1} \mathrm{DM}$ & $5.92^{f}$ & $10.27^{e}$ & $14.93^{\mathrm{d}}$ & $18.92^{c}$ & $20.81^{b}$ & $25.59^{a}$ & 0.87 & $<0.001$ \\
\hline Retinol, $\mathrm{mg} \cdot \mathrm{kg}^{-1} \mathrm{DM}$ & 10.40 & 10.17 & 10.79 & 11.00 & 10.45 & 10.98 & 0.10 & NS \\
\hline$\alpha$-Tocopherol, $\mathrm{mg} \cdot \mathrm{kg}^{-1} \mathrm{DM}$ & 166.0 & 160.0 & 174.1 & 171.9 & 170.6 & 174.6 & 1.75 & NS \\
\hline $\mathrm{MDA}_{0}, \mathrm{mg} \cdot \mathrm{kg}^{-1}$ & $0.384^{\mathrm{abc}}$ & $0.358^{c}$ & $0.405^{\mathrm{a}}$ & $0.393^{a b}$ & $0.359^{b c}$ & $0.321^{d}$ & 0.006 & $<0.001$ \\
\hline $\mathrm{MDA}_{28}, \mathrm{mg} \cdot \mathrm{kg}^{-1}$ & $0.819^{\mathrm{a}}$ & $0.749^{b}$ & $0.726^{b}$ & $0.736^{b}$ & $0.616^{c}$ & $0.533^{d}$ & 0.014 & $<0.001$ \\
\hline
\end{tabular}

${ }^{1}$ lipid peroxidation level - thiobarbituric acid reactive substances (TBARS) content expressed as $\mathrm{mg}$ of malondialdehyde (MDA) per egg kg; ${ }^{2} \mathrm{DM}$ - dry matter; ${ }^{\text {a-f }}$ see Table 4; NS - not significant

the concentration of retinol or $\alpha$-tocopherol in the eggs observed (Table 5).

Currently, there is a tendency to replace synthetic feed additives with natural substances derived from plants, which are free from undesirable side effects. It was shown in our previous study that spraydried Chlorella is a suitable source of carotenoids that quadrupled the concentration of lutein and zeaxanthin in yolks and increased the oxidative stability of yolk lipids when compared with the control group and group with addition of Carophyll ${ }^{\circledR}$ Red (Englmaierová et al., 2013). Positive effect of carotenoids on oxidative stability was observed also in the case of grazing (Skrrivan et al., 2014, 2015b). In the present study, hens fed diet with $950 \mathrm{mg}$ of MFE per $\mathrm{kg}$ (which is about $9.5 \mathrm{mg}$ lutein per $\mathrm{kg}$ ) deposited lutein and zeaxanthin in the amount of 7.5 and $5.3 \mathrm{mg}$ per $100 \mathrm{~g}$ of egg yolk, respectively. MFE at dose of $150 \mathrm{mg} \cdot \mathrm{kg}^{-1}$ increased the lutein and zeaxanthin in yolks by 62.9 and $73.3 \%$, respectively. In group fed diet with $950 \mathrm{mg}$ of MFE per $\mathrm{kg}$ of diet, the concentration of both carotenoids tripled in comparison with the control group. Lokaewmanee et al. (2011) reported that hens fed MFE in the amount of $443 \mathrm{mg} \cdot \mathrm{kg}^{-1}$ diet containing $10 \mathrm{mg}$ of lutein per kg deposited lutein and zeaxanthin in the amount of 1.8 and $0.7 \mathrm{mg}$ per $100 \mathrm{~g}$ of egg yolk, respectively. In Japanese quails fed diet with addition of $2 \mathrm{~g}$ of MFE per $\mathrm{kg}$ of diet (10.6 mg of lutein per $\mathrm{kg}$ ), the egg yolks contained lutein and zeaxanthin in the amount of 3.11 and $0.30 \mathrm{mg}$ per 100 g, respectively (Karadas et al., 2006). The deposition of lutein and zeaxanthin in egg yolk may be influenced by the composition of the basal diet. 
For example, adding linseed to diets supplemented with lutein depressed the yolk lutein content (Leeson and Caston, 2004).

Green leafy vegetables and eggs are the major food sources of lutein and zeaxanthin in most human diets (Johnson et al., 2010). The presence of both xanthophylls in food is beneficial for human health. Lutein and zeaxanthin are deposited in the macular region of the retina and reduce the risk of age-related macular degeneration (Landrum et al., 1999). At present, there is no recommended daily intake for lutein and zeaxanthin. However, a recent doseresponse meta-analysis showed that every $0.3 \mathrm{mg}$ per day increment in dietary lutein and zeaxanthin intake was associated with a 3\% reduction of the nuclear cataract risk, which is the most common type of cataract (Ma et al., 2014). In the present study, the contents of lutein and zeaxanthin in a $60 \mathrm{~g}$ egg from the control hens were 0.37 and $0.18 \mathrm{mg}$, respectively, whereas in hens fed diet with $950 \mathrm{mg}$ of MFE per $\mathrm{kg}$ of diet the corresponding lutein and zeaxanthin contents were 1.09 and $0.77 \mathrm{mg}$, respectively. The daily intake of lutein and zeaxanthin in humans is variable (Bone et al., 2000). In people consuming less than $1 \mathrm{mg}$ lutein and zeaxanthin daily, one luteinenriched egg per day provides protection to the eye against oxidative stress and the development of agerelated macular degeneration.

Dietary MFE increased in a dose-dependent manner the yolk colour score assessed using the DSM Yolk Colour Fan from 5.67 to 10.55 as well as redness of the yolk (from 4.94 to 11.51; Table 4). Also yellowness of the yolk increased but from the amount of $550 \mathrm{mg}$ of MFE per kg of diet this parameter was kept on stable level. The decrease in yolk lightness was observed for all experimental groups. In the previous experiment performed by Skrrivan et al. (2015a), MFE supplementation at a dose of 250 and $350 \mathrm{mg} \cdot \mathrm{kg}^{-1}$ increased the yolk colour score measured with the use of DSM Yolk Colour Fan identically to 8.9. It is well recognized that yolk colour is important for consumers. It was estimated that deeply hued yolks are the most popular all over the world (Beardsworth and Hernandez, 2004).

Synthetic carotenoids are routinely used in poultry diets to increase yolk pigmentation and to improve the lipid oxidative stability. If canthaxanthin, present in Carophyll ${ }^{\circledR}$ Red and Lucantin ${ }^{\circledR}$ Red, is added to the laying hens feed, a maximum of $8 \mathrm{mg} \cdot \mathrm{kg}^{-1}$ is allowed, supposing that the total concentration of canthaxanthin and other carotenoids does not exceed $80 \mathrm{mg} \cdot \mathrm{kg}^{-1}$ (EU Commission Directive 2003/7/EC). The use of synthetic carotenoids is not allowed in organic farming. The acute oral toxicity of canthaxanthin is very low. Experiments conducted on monkeys revealed that the oral administration of canthaxanthin was associated with crystalline deposits in the retina. The grade of crystals in monkey retinas was dose dependent, with a threshold level at $0.6 \mathrm{mg}$ of canthaxanthin per $\mathrm{kg}$ body weight per day (Goralczyk et al., 2000). A similar observation based on the biostatistical eva-luation of 411 cases was reported previously in humans(Köpckeetal., 1995).TheEFSAPanelonFood Additives and Nutrient Sources added to Food (EFSA, 2010) thus allocated an acceptable daily intake of canthaxanthin at the amount of $0.03 \mathrm{mg} \cdot \mathrm{kg}^{-1}$ body weight per day (using an uncertainty factor of 10).

\section{Conclusions}

It can be concluded that marigold flower extract (MFE) supplementation to laying hen diet influence egg production and its quality. The most recommended dose would be $550 \mathrm{mg}$ of MFE per $\mathrm{kg}$ of diet. This amount is optimal in terms of increasing egg production and efficiency of yolk enrichment with carotenoids, which have positive influence on yolk colour and increase oxidative stability of lipids in stored eggs. So it can be stated that MFE is a suitable alternative to commercial synthetic xanthophylls.

\section{Acknowledgements}

This study was supported by the Ministry of Agriculture of the Czech Republic, Project No. QJ1310002 and MZERO0714.

\section{References}

AOAC International, 2005. Official Methods of Analysis of AOAC International. $18^{\text {th }}$ Edition. Gaithersburg, MD

Al-Harthi M.A., El-Deek A.A., 2012. Effect of different dietary concentrations of brown marine algae (Sargassum dentifebium) prepared by different methods on plasma and yolk lipid profiles, yolk total carotene and lutein plus zeaxanthin of laying hens. Ital. J. Anim. Sci. 11, 347-353

Altuntaş A., Aydin R., 2014. Fatty acid composition of egg yolk from chickens fed a diet including marigold (Tagetes erecta L.). J. Lipids 2014, ID564851, doi:dx.doi.org/10.1155/2014/564851

Beardsworth P.M., Hernandez J.-M., 2004. Yolk colour - an important egg quality attribute. Int. Poultry Prod. 12, 17-18

Bone R.A., Landrum J.T., Dixon Z., Chen Y., Llerena C.M., 2000. Lutein and zeaxanthin in the eyes, serum and diet of human subjects. Exp. Eye Res. 71, 239-245

Chowdhury S.D., Hassin B.M., Das S.C., Rashid M.H., Ferdaus A.J.M., 2008. Evaluation of marigold flower and orange skin as sources of xanthophyll pigment for the improvement of egg yolk color. J. Poultry Sci. 45, 265-272 
EFSA, 2010. Scientific opinion on the re-evaluation of canthaxanthin (E $161 \mathrm{~g})$ as a food additive. EFSA J. 8, 1852

EN 12822, 2000. Foodstuffs - Determination of vitamin E by high performance liquid chromatography - Measurement of $\alpha-, \beta-, \gamma-$ and $\delta$-tocopherols. European Committee for Standardization. Brussels (Belgium)

EN 12823-1, 2000. Foodstuffs - Determination of vitamin A by high performance liquid chromatography - Part 1: Measurement of all-trans-retinol and 13-cis-retinol. European Committee for Standardization. Brussels (Belgium)

EN 12823-2, 2000. Foodstuffs - Determination of vitamin A by high performance liquid chromatography - Part 2: Measurement of $\beta$-carotene. European Committee for Standardization. Brussels (Belgium)

Englmaierová M., Skřivan M., Bubancová I., 2013. A comparison of lutein, spray-dried Chlorella, and synthetic carotenoids effects on yolk colour, oxidative stability, and reproductive performance of laying hens. Czech J. Anim. Sci. 58, 412-419

Englmaierová M., Skřivan M., Skřivanová E., Bubancová I., Čermák L., Vlčková J., 2015. Effects of a low-phosphorus diet and exogenous phytase on performance, egg quality, and bacterial colonisation and digestibility of minerals in the digestive tract of laying hens. Czech J. Anim. Sci. 60, 542-549

EU, 2003. Commission Directive 2003/7/EC of 24th January 2003 amending the conditions for authorisation of canthaxanthin in feedingstuffs in accordance with Council Directive 70/524/ EEC. Off. J. Eur. Commun. L 22, 28-30

EU, 1999. Council Directive 1999/74/EC of 19 July 1999 laying down minimum standards for the protection of laying hens. Off. J. Eur. Commun. L 203, 53-57

Fredriksson S., Elwinger K., Pickova J., 2006. Fatty acid and carotenoid composition of egg yolk as an effect of microalgae addition to feed formula for laying hens. Food Chem. 99, 530-537

Froescheis O., Moalli S., Liechti H., Bausch J., 2000. Determination of lycopene in tissues and plasma of rats by normal-phase high-performance liquid chromatography with photometric detection. J. Chromatogr. B Biomed. Sci. Appl. 739, 291-299

Goralczyk R., Barker F.M., Buser S., Liechti H., Bausch J., 2000. Dose dependency of canthaxanthin crystals in monkey retina and spatial distribution of its metabolites. Invest Ophthalmol Vis Sci. 41, 1513-1522

Hammershøj M., Kidmose U., Steenfeldt S., 2010. Deposition of carotenoids in egg yolk by short-term supplement of coloured carrot (Daucus carota) varieties as forage material for egg-laying hens. J. Sci. Food Agric. 90, 1163-1171

Haugh R.R., 1937. The Haugh unit for measuring egg quality. US Egg Poultry Mag. 43, 552-555, 572-573

Johnson E.J., Maras J.E., Rasmussen H.M., Tucker K.L., 2010. Intake of lutein and zeaxanthin differ with age, sex, and ethnicity. J. Am. Diet. Assoc. 110, 1357-1362
Karadas F., Grammenidis E., Surai P.F., Acamovic T., Sparks N.H., 2006. Effect of carotenoids from lucerne, marigold and tomato on egg yolk pigmentation and carotenoid composition. Brit. Poultry Sci. 47, 561-566

Köpcke W., Barker F.M., Schalch W., 1995. Canthaxanthin deposition in the retina: a biostatistical evaluation of 411 patients. J. Toxicol. Cutan. Ocul .Toxicol. 14, 89-104

Kotrbáček V., Skrivvan M., Kopecký J., Pěnkava O., Hudečková P., Uhríková I., Doubek J., 2013. Retention of carotenoids in egg yolks of laying hens supplemented with heterotrophic Chlorella. Czech J. Anim. Sci. 58, 193-200

Landrum J.T., Bone R.A., Chen Y., Herrero C., Llerena C.M., Twarowska E., 1999. Carotenoids in the human retina. Pure Appl. Chem. $71,2237-2244$

Leeson S., Caston L., 2004. Enrichment of eggs with lutein. Poultry Sci. 83, 1709-1712

Lokaewmanee K., Mompanuon S., Khumpeerawat P., Yamauchi K., 2009. Effects of dietary mulberry leaves (Morus alba L.) on egg yolk color. J. Poultry Sci. 46, 112-115

Lokaewmanee K., Yamauchi K., Komori T., Saito K., 2011. Enhancement of yolk color in raw and boiled egg yolk with lutein from marigold flower meal and marigold flower extract. J. Poultry Sci. 48, 25-32

Ma L., Hao Z.X., Liu R.R., Yu R.B., Shi Q., Pan J.P., 2014. A dose-response meta-analysis of dietary lutein and zeaxanthin intake in relation to risk of age-related cataract. Graefes Arch Clin Exp Ophthalmol. 252, 63-70

Mader P., Mikolášek A., Lidická M., Nováková V., Hartlová L., Staněk J., 1984. Algae as a natural source of carotenoids in laying hen feed mixtures (in Czech). Živoč. Výr. 29, 557-567

Piette G., Raymond Y., 1999. Comparative evaluation of methods to determine rancidity in processed meat (in German). Fleischwirtschaft 7, 69-73

SAS, 2003. SAS/STAT User's Guide (release 9.2). SAS Institute. Cary, NC

Skrivan M., Englmaierová M., 2014. The deposition of carotenoids and a-tocopherol in hen eggs produced under a combination of sequential feeding and grazing. Anim. Feed Sci. Tech. 190, 79-86

Skřivan M., Englmaierová M., Skřivanová E., Bubancová I., 2015a. Increase in lutein and zeaxanthin content in the eggs of hens fed marigold flower extract. Czech J. Anim. Sci. 60, 89-96

Skřivan M., Pickinpaugh S.H., Pavlů V., Skřivanová E., Englmaierová M., 2015b. A mobile system for rearing meat chickens on pasture. Czech J. Anim. Sci. 60, 52-59

Zahroojian N., Moravej H., Shivazad M., 2011. Comparison of marine algae (Spirulina platensis) and synthetic pigment in enhancing egg yolk colour of laying hens. Brit. Poultry Sci. 52, 584-588 